\title{
Kobieta, figura, kanon
}

Arkadiusz Bagłajewski

TEKSTY DRUGIE 2018, NR 5, S. 152-165

DOI: $10.18318 /$ td.2018.5.10

Dod nijaką okładką skrywa się książka fascynująca. Niejasny tytuł - ...czterdzieści i cztery. Figury literackie. Nowy Kanon ${ }^{1}$ - składający się z trzech członów domaga się wyjaśnienia. I wyjaśnienie znajdziemy we wstępie, napisanym przez dwie spośród ośmiu redaktorek książki: Monikę Rudaś-Grodzką i Barbarę Smoleń.

Więc „czterdzieści i cztery" - wiemy, że w Mickiewiczowskim arcydramacie pojawia się tajemnicza postać, osnuta aurą mesjanistycznego proroctwa. Kim jest ta zagadka fascynowała kolejne pokolenia czytelników Dziadów części III. Oczywiście zagadka nierozwiązana, niejasna zarówno dla samego twórcy, jak i jego czytelników, choć nie ulegało dla nich wątpliwości, że to zgodnie z wykładnią tekstową „wskrzesiciel narodu”. Oczekiwany

\section{Arkadiusz \\ Bagłajewski - \\ dr hab., pracownik \\ Instytutu Filologii Pol- \\ skiej UMCS. Zajmuje \\ się romantyzmem \\ i współczesnością. \\ Ostatnio wydał \\ książkę Obecność \\ romantyzmu, Lublin \\ 2015. Kontakt: bagla- \\ jewski@go2.pl.}

1 ...czterdzieści i cztery. Figury literackie. Nowy kanon red. M. Rudaś-Grodzka, B. Smoleń, K. Nadana-Sokołowska, A, Mrozik, K, Czeczot, A. Nasiłowska, E. Serafin-Prusator, A. Wróbel, Wydawnictwo IBL PAN, Warszawa 2017. Seria: "Lupa Obscura”. W dalszej części omówienia cytaty lokalizuję bezpośrednio w tekście, w nawiasie podając numer strony. 
i w niektórych momentach narodowej historii wypełniony treścią - ucieleśniony. Autorki wstępu piszą - wielce sugestywnie, ale czy w zgodzie kontekstem Widzenia księdza Piotra? - o tej postaci jako figurze milczącej, niewidocznej, czekającej na swój moment w dziejach. „Postać zamaskowanego zbawcy powraca w naszej kulturze nieustannie, przypomina się, ale nie daje do końca odczytać" (s. 11). Dalej czytamy, że jest ta postać figurą tego, co marginalne, niedopoznane, co czeka na wydobycie, tak by mogło przemieścić się z marginesów ku centrum. Autorki wstępu wskazują na subwersywny i rewolucyjny potencjał tkwiący w owej figurze. I oczywiście zwłaszcza w czterdziestu czterech innych, będących przedmiotem nader wnikliwej refleksji. Tyle że Mickiewiczowska figura - z nie do końca jasnych dla mnie powodów - przyzywa inne i, ustępując im miejsca, wyznacza w zamyśle redaktorek kształty „nowego kanonu”. Będą to figury związane z kobiecością, dobrane nadzwyczaj intrygująco, wywrotowe, niedoczytane, zdolne do przeformułowania i przeorientowania kulturowego.

Figura jest tu rozumiana, przytoczę dłuższy cytat, gdyż jest on ważny, w sensie metodologicznym i tożsamościowym, jako

postać historyczna lub fikcyjna, która w procesie zmian historycznych i społecznych nabrała znaczenia albo symbolicznego, albo alegorycznego, stając się podejmowanym i reinterpretowanym wciąż na nowo przez kolejne pokolenia wątkiem kulturowym znacząco wpływającym na konstrukcje tożsamościowe, uwikłane w kategorię płci kulturowej, takie jak naród, wspólnota, klasa, rasa czy mniejszość seksualna. Ujęcie to pozwoliło na krytyczną rekonstrukcję wyobrażeń, mitów, fantazmatów i figur odgrywających ważną rolę w naszej historii i symbolice narodowej z uwzględnieniem perspektywy krytyki feministycznej, postkolonialnej i gender. (s. 11-12)

Pomijając lapsus, jakim jest definiowanie „figury” jako figury (pośród mitów i fantazmatów), wszystko jest tu ważne, stąd owo dłuższe przytoczenie. Oto pojawia się na prawie siedmiuset stronicach leksykonu czterdzieści i cztery postaci/figur kobiecych, wydobywanych z różnych dzieł kultury polskiej, zasadniczo od romantyzmu do współczesności (wyjąwszy Urszulę Kochanowską i Barbarę Radziwiłłównę). Dominują figury wyprowadzone, by tak rzecz ująć, z dzieł literackich, choć pojawiają się z innych obszarów kultury, jak „Marusia (Ogoniok)” z serialu Czterej pancerni i pies czy „Natalia w Brooklynie" z popularnej piosenki Kazika. 
Czterdzieści i cztery postaci/figury - odczytywane w perspektywie feministycznej, genderowej czy postkolonialnej - mają ujawnić swój potencjał rewizyjny, wywrotowy, tak by w efekcie zbiorowej pracy intelektualnej można było postawić solidne fundamenty pod gmach "nowego kanonu” (to trzeci termin pojawiający się w formule tytułowej tomu).

Powiem od razu, że jest oczywiste dla autorek i autorów zebranych prac, iż ich rozpoznania interpretacyjne są propozycją zbudowania kanonu feministyczno-genderowego, będącego kontrkanonem (posługuję się tu rozumieniem terminu zaproponowanym niegdyś przez Germana Ritza ${ }^{2}$ ) wobec nienazwanego tu wprost, ale przecież stale obecnego w kontekście działań rewizyjnych, kanonu znanego z tradycyjnej wersji historycznoliterackiej, w której patriarchalny ogląd zjawisk bywał traktowany jako jedynie obiektywna miara rzeczy. Nie kreślę bynajmniej tych słów z ironią - sam byłem kształtowany polonistycznie w przekonaniu o istnieniu obiektywnej, esencjalnej prawdy, kryjącej się za zasłoną różnych literackich form, do której można dotrzeć po opanowaniu sprawnych i sprawdzalnych, rzecz jasna, narzędzi interpretacyjnych. Więc w tamtym kanonie byli Tadeusz i Jacek Soplica - w tym tu proponowanym Zosia i Telimena. Miejsce Rzeckiego i Wokulskiego - zajmuje Izabela. Ale subwersywność ma jeszcze inny wymiar i to jest ważniejsze jako gest przeczytania od nowa, nowymi narzędziami postaci obecnych i wcześniej w tak czy inaczej definiowanym kanonie „ogólnonarodowym”: była tam i Dulska, i Madzia Brzeska, i Jagna czy Emilia Plater. (Zwłaszcza w szkolnym "przerabianiu”, te i inne postaci kobiece uzyskiwały kształty kanoniczne, wyznaczone arbitralnym wszak wyborem tekstów). Wszakże dopiero lektura zgromadzonych prac uświadamia, jak dalece wcześniejsze interpretacje (oczywiście ze świadomością istnienia szkolnych uproszczeń) były nie tylko niewystarczające, ale wymijały „centralne” problemy, gdyż wydawało się, że są one na "marginesach", problemy, związane z projektami tożsamościowymi, jak emancypacja, czy propozycjami budowania alternatywnych wspólnot, np. w projekcie nauczycielskim z końca XIX wieku. Do tych kwestii przyjdzie jeszcze wrócić. Tu chciałbym powiedzieć, że propozycja "nowego kanonu” rysuje się po lekturze całości wyraziście, jakkolwiek można byłoby przecież znacząco poszerzyć listę figur o kolejne „czterdzieści i cztery”. Rzecz jednak nie w takich czy innych pominięciach czy nieobecnościach. Listę dałoby się ad hoc stworzyć całkiem pokaźną. Ale mijałoby się to z celem, byłby to strzał

2 G. Ritz Kanon i historia literatury widziane z zewnątrz, w: Kanon i obrzeża, red. I. Iwasiów, T. Czerska, Universitas, Kraków 2005. 
obok. Chcę powiedzieć to wyraźnie - już zebrany na stronicach omawianej pracy materiał w pełni potwierdza wyraźne kontury owego „nowego kanonu" (mniejsza o szczegóły, ale bardziej fortunny wydawałby mi się termin „inny kanon”, nie tracąc rewizyjnego charakteru, zwracałby uwagę na kwestię w czasach wielu rozchwianych kanonów kluczową, mianowicie (do)wolność w wytyczaniu kanonów, ich prywatnościowy charakter).

Czytam we wstępie, że w centrum owego "nowego kanonu” znajduje się figura „Polonii", kluczowa wszak i w uprzednim kanonie wolnościowym, zwanym w wykładni Marii Janion jako „romantyczno-symboliczny”. Posłuchajmy, co o figurze Polonii piszą autorki wstępu, parafrazując ustalenia autorki Niesamowitej Słowiańszczyzny. Otóż po utracie niepodległości

Polonia jako martwa kobieta stała się głównym narodowym fantazmatem. Cała polska nowożytna wrażliwość skupiła się na melancholijnych obrządkach skupionych wokół wyobrażonych kobiecych zwłok, które stały się czczoną relikwią i tworzywem pamiątek. [...] Kobieta-Polonia jako ciało narodu, [...] stała się ośrodkiem patriotycznej religii. (s. 12)

Jeśli obserwacja ta jest słuszna, to pewne zdziwienie budzi brak obszernego hasła poświęconego figurze Polonii (hasło „Matka Polka” Kazimiery Szczuki w części wypełnia tę lukę). Można wszak było przedrukować esej Janion pt. Polonia powielona ${ }^{3}$, obudowując go szczegółowymi glosami, jak przykładowo poświęcona „Matce Polce”. Przydałby się tu głos historyka/historyczki sztuki, tym bardziej że cenne prace Ryszkiewicza, Porębskiego, Okonia ${ }^{4}$ gromadzą bogaty i różnorodny materiał ikonograficzny. Powiem na marginesie omówienia, że aż się prosi o poszerzenie egzemplaryczne Polonii o wyobrażenia/ fantazmaty "Matki-Ukrainy” chociażby, jak je nazwał w swych Alegoriach narodowych Waldemar Okoń ${ }^{5}$ (poszerzone, rzecz jasna, o przykłady z utworów literackich). Dopiero tak szeroki materiał - z literatury i sztuki porozbiorowej

3 M. Janion Polonia powielona, w: tejże, Niesamowita Słowiańszczyzna. Fantazmaty literatury, Wydawnictwo Literackie, Kraków 2006.

4 A. Ryszkiewicz Alegorie i satyry na kilka momentów z historii Polski przełomu XVIII i XIX wieku, w: Ikonografia romantyczna. Materiały sympozjum Komitetu Nauk o Sztuce PAN. Nieborów 26-28 czerwiec 1975, red. M. Poprzęcka, Ossolineum, Wrocław 1977; M. Porębski Interregnum. Studia z historii sztuki polskiej XIX i XX wieku, PIW, Warszawa 1975; W. Okoń Alegorie narodowe. Studia z dziejów sztuki polskiejXIX wieku, Wydawnictwo UWr, Wrocław 1992.

5 W. Okoń „Matka-Ukraina”, w: tegoż Alegorie narodowe... 
kilku epok - pozwoliłby na uprawomocnienie, a przynajmniej mocne wybrzmienie, tezy o kluczowej dla polskiego imaginarium i mentalności ostatnich dwu stuleci figurze „Matki Polonii/ Ukrainy/ Lituanii”. Ta trójczłonowa nazwa nie wyrasta bynajmniej z obcych mi zapędów imperialnych, lecz wskazuje na bliski myśleniu dawnych epok związek „trójjedności” ziem dawnej Rzeczypospolitej ze współczesną możliwością (koniecznością?) zastosowania instrumentarium genderowego i postkolonialnego do jego dekonstrukcji. Nie ulega dla mnie wątpliwości, że byłoby to postępowanie ze wszech miar naukowo fortunne, przynoszące - a formułuję te uwagi po lekturze rozprawy Janion - bardzo ważne ustalenia, rezonujące przy tym z zamętem naszej współczesności. Krytyczna analiza owego kompleksu wyobrażeń, podjęta narzędziami metodologii stosowanymi na kartach omawianego leksykonu, pozwoliłaby skutecznie rozbroić nacjonalistyczne i niekiedy megalomańskie mity, dając, mam nadzieję, że odkrywcze, rozpoznania ambiwalencji owej „troistej” figury: w której „matczyna” więź z „dziećmi” sąsiaduje niewątpliwie z wstydliwymi prawdami o tym, że niektóre spośród owych „dzieci” bywały traktowane w kulturze polskiej jako „bękarty” - byty niższe, wykluczone, pozbawiane głosu. Ów rewizyjny potencjał pojawia się, rzecz jasna, w ostatnio wydawanych publikacjach, jak chociażby w książce Moniki Rudaś-Grodzkiej ${ }^{6}$ czy tomach Romantyzmu środkowoeuropejskiego w kontekście postkolonialnym ${ }^{7}$.

Myślę, że omawiany tom warto czytać w szerszym kontekście podejmowanych w ostatnich latach prób - udanych przecież - rewizji romantycznych i poromantycznych mitów tożsamościowo-narodowościowych. Nie podejmując szerzej tego wątku, chciałbym wszakże zwrócić uwagę na fakt, że bez dokonującego się w polskiej humanistyce genderowego i postkolonialnego zwrotu trudno byłoby liczyć na efektywność takiego przedsięwzięcia, jakie przynosi tom ...czterdzieści i cztery. To, że ten typ badań z nowinki, z marginesu, powoli acz skutecznie przemieścił się do centrum współczesnej refleksji naukowej, że „systematyzowanie wiedzy niesystemowej” (zwieńczone chociażby publikacją Encyklopedii gender tego samego środowiska, które przygotowało do druku omawianą książkę), jak to ujął w recenzji ważnych publikacji

6 M. Rudaś-Grodzka Sfinks słowiański i mumia polska, Wydawnictwo IBL PAN, Fundacja Akademia Humanistyczna, Warszawa 2013.

7 Romantyzm środkowoeuropejski w kontekście postkolonialnym, cz. I, red. M. Kuziak, B. Nawrocki, Wydawnictwo IBL PAN, Warszawa 2017. Seria: „Studia Romantyczne” I, Romantyzm środkowoeuropejski w kontekście postkolonialnym, cz. II, red. M. Kuziak, B. Maciejewski, Universitas, Kraków 2016. Seria: „Projekty Komparatystyki”. 
genderowych Przemysław Górecki ${ }^{8}$, jest faktem niepodlegającym już dyskusji, sprawiło, że ustabilizowała się nie tylko pewna siatka pojęciowa i aplikacja metod, opartych na przyswojonych w humanistyce polskiej ujęciach z prac obcych wraz z ich twórczą aplikacją na rodzimy grunt, ale mogło dojść do wytyczenia nowych obszarów badawczych. Mówiąc w pewnym skrócie - zastosowanie metodologii sprzęgnięte zostało wyraźnie z konkretnymi praktykami interpretacyjnymi. Owe praktyki czerpią, co prawda, z instrumentarium literaturoznawczego i ze studiów kulturowych, zmierzają wszakże do pewnych uogólnień wykraczających poza literaturoznawstwo, śmiało wkraczając na tereny refleksji kulturowej. W ten oto sposób dostajemy - w praktyce - przykłady stosowania nowszych narzędzi, które otwierają odmienne od dotychczas funkcjonujących ujęć możliwości interpretacyjne na szerszym polu kultury, nie zaś wyłącznie na literaturoznawczej jego części - powiązane są one w dodatku z kontekstem kultury światowej. By nie być gołosłownym, sięgnę po wybrane przykłady ze zgromadzonych w tomie haseł.

Ale zanim do tego przejdę, jeszcze słowo na temat zaproponowanej formuły alfabetycznego leksykonu. Jest ona fortunna, acz niepozbawiona pewnych mankamentów. Podstawowym jest zamazanie pewnego istniejącego wszak w kulturze rytmu: ciągłości, dopływów, uskoków w pewnych większych całostkach, jak tendencja, nurt, zjawisko etc. Trudno np. w leksykonie prześledzić dokonującą się kulturze polskiej linię emancypacyjną - zarówno w nurcie "głównym”, jak i w licznych „odnogach bocznych". Przykładowo: przejście od „Aspazji” i „Białej Róży”, przez figury „Szalonej”, ,Madzi Brzeskiej”, ,Marty”, „Siłaczki” po „Iwonę" i „Zutę Młodziakównę”, i dalej - po „Helę Traktorzystkę" i „Natalię w Brooklynie”, gdyby zostało zebrane w książce w takim mniej więcej porządku, pozwoliłoby ukazać ową dynamikę dokonującej się zmiany kulturowej. W formule leksykonu owa dynamika może nie tyle nawet ginie, ale jest znacząco osłabiana, trudno bowiem wymagać, by każdy odbiorca przeczytał/każda odbiorczyni przeczytała tę całość od deski do deski (choć ja zachęcam do takiej lektury - naprawdę warto!).

I jeszcze jedna kwestia podnoszona przez autorki wstępu. Otóż piszą one, że odsłanianemu kanonowi towarzyszą realne biografie. Są one raz bliżej, innym razem dalej od interpretowanej figury. Ale są i ją na swój sposób dopełniają oraz wyznaczają jej kształty. Kiedy czytamy o „Matce Joannie od Aniołów" (hasło autorstwa Sebastiana Dudy i Emilii Kolinko) - to swoistym

8 P. Górecki Z marginesu do centrum. Encyklopedia gender i inne nowe omówienia dyscypliny gender studies, "Teksty Drugie” 2017 nr 1, s. 132-133. 
„dopełnieniem" - jakże przy tym dramatycznym - jest przywołana historia Barbary Ubrykówny, „opętanej” i poddanej w swym „szaleństwie” radykalnej operacji zamknięcia w celi i pozbawienia głosu. Ale też wskazywana jest zaskakująca - i przyznać trzeba, że dość dyskusyjna, choć niepozbawiona inspirujących aspektów - paralela między bohaterką opowiadania Iwaszkiewicza a Anną Iwaszkiewiczową, tak jak „matka Joanna” pragnącej świętości. Ale czy możemy tu mówić o „opętaniu”, nawet jeśli faktem jest kryzys nerwowy Iwaszkiewiczowej? Inną postacią realną, związaną z figurą - Marii z powieści poetyckiej Malczewskiego - jest Gertruda Komorowska. Jak wiadomo, ów „pierwowzór” Marii - pierwsza żona Szczęsnego Potockiego - tajnie poślubiona wbrew woli rodziców Szczęsnego, porwana i w niejasnych okolicznościach zamordowana, stała się bohaterką ,czarnej” legendy, w której pycha magnacka i zbrodnia zostały połączone mocnym węzłem. Ale romantyk Malczewski sublimuje tę „czarną” legendę - wyraźnie przecież podkreśla jej "anielskość", nierozłącznie wszakże rymującą się ze śmiercią. Winteresująco pomyślanym haśle autorstwa Aleksandry Sekuły razi wszakże „wynalazczość” językowa autorki, niepotrzebnie bliska pragnieniu powiedzenia czegoś, co jest znane, „nowym” językiem. Czy jednak „nowym”, jeśli niepokojąco bliski jest on poetyce streszczenia, niewolnej od przykrych potknięć stylistycznych: przeczytamy o tym, że „Maria hipnotycznie wpatruje się w szczeliny połączenia z ukochanym” (s. 379), „Po scenie zanurzenia w samotność i rozpacz Maria, [...] oddaje się śledzeniu wzrokiem odjeżdżających żołnierzy, [...]" (s. 380), „Do Marii, [...] dotrzeć można tylko poprzez step - [...]” (s. 381) czy w zakończeniu wywodu - „sterczał jak wykrzyknik trup ofiary” (s. 396).

To nie wszystkie, rzecz jasna, przykłady spotkania „realnej” osoby z figurą, bowiem odniesienia sięgać mogą daleko w historię, jak w przypadku Urszuli Kochanowskiej i jej figuralnego odniesienia do Anki Broniewskiego czy już bliższych nam czasów - Papuszy, będącej figuralnym wariantem Azy (Cyganki). Czy w innej perspektywie Żmichowskiej i Wandy Żeleńskiej wobec figury „Białej Róży”. Owe odniesienia są różnej, by tak rzec, relacyjnej intensywności: od śladu po ponowienie, przy czym bywa, że figura wyprzedza życie, ale też i dzieje się odwrotnie, jak w przypadku Faustyny Morzyckiej, będącej pierwowzorem „Siłaczki”.

Wracając do przerwanego wątku, odnoszącego się do ujęcia rewizyjnego, widocznego w sposobach tworzenia hasła. Oto pierwsze hasło w leksykonie: „Aspazja”, autorstwa Ewy Serafin-Prusator może być dogodnym polem obserwacji ogólniejszej metody rewizyjnej, wyrastającej z przyjętego na potrzeby publikacji sposobu konstruowania hasła (acz trzeba dodać, że 
hasła mają autorski charakter, różnią się niekiedy znacznie, także poziomem naukowego wykonania, i jeśli mówię o pewnym wypracowanym wariancie leksykologicznym, to pamiętam o jego elastycznej formule, wyznaczanej każdorazowo przez autorkę/autora i sam materiał). Autorka hasła poświęconego bohaterce ważnej powieści Narcyzy Żmichowskiej sytuuje postać powieściowej Aspazji w kontekście kulturowym: zrazu Aspazji z Miletu, ukazując jej ambiwalentne ujęcie, a następnie w dalszym wywodzie pojawia się kontekst piśmiennictwa europejskiego z epoki, zwłaszcza figura wampira. Obszerna analiza zmierza do wskazania subwersywnego potencjału Aspazji z wersji Żmichowskiej: podważającej patriarchalne ograniczenia. Oczywiście te wnioski wsparte są na wnikliwej analizie m.in. wyobrażeń onirycznych i przestrzennych, zwłaszcza tych, które pseudonimują to, co podświadome. Pozostając przy Żmichowskiej - w świetnej interpretacji Białej Róży Katarzyna Nadana-Sokołowska ukazała w odkrywczy sposób formowanie związków między kobietami, protofemistycznej wspólnoty w języku, który dopiero się klaruje, w serii napomknięć, niejasnych aluzji (przywołany jest też kontekst tzw. „małżeństw bostońskich), pewnego kodu odnoszonego do kultury greckiej. Nie jest to powieść o lesbijskim związku, ale czy o lesbijce - zastanawia się autorka hasła. I daje odpowiedź mocno zanurzoną w świecie powieści Żmichowskiej, wieloznaczną, choć z wyraźną konkluzją: „Białą Różę można zatem uznać za figurę niewypowiadalnego pragnienia związku kobiety z kobietą w kulturze polskiej" (s. 99).

W haśle poświęconym Barbarze Radziwiłłównie Inga Iwasiów w inny jeszcze sposób tropi, wydobywa i ujawnia znaczenia figury w perspektywie nie tylko „kanonicznej” w kulturze polskiej wersji Felińskiego, ale też odkrywczo ukazuje przemieszczenia sensów, sięgając po współczesny kontekst litewski. Jak pisze autorka - Barbara jest i polska, i litewska, zaś w swej „nowej" (litewskiej) odsłonie służy swoistemu nacjonalistycznemu umacnianiu tożsamości współczesnej kultury litewskiej. Ale tak jak „niepełny” to wariant figury, tak samo jej polska „wersja” (znana z tragedii neoklasycystycznej) wydaje się dziś niewystarczająca. $\mathrm{Na}$ „podwójność" figury Judyty - bohaterki Księdza Marka - zwróciła uwagę Monika Rudaś-Grodzka. To Żydówka, stygmatyzowana Inna, obca, ale równocześnie figuralna zapowiedź „nowych czasów" (w mistycznej koncepcji dziejów). Słowacki zrywa ze stereotypem bohatera żydowskiego jako postaci komicznej. Jego Judyta - „ogromnieje”. Jest przedmiotem wzgardy i narzędziem Boskiego wybraństwa. Erudycyjny wywód autorki hasła, podkreślający wywrotowy charakter starotestamentowej Judyty, następnie odnoszony do bohaterki Słowackiego, pozwala ujawnić 
w tej figurze religijny, polityczny i seksualny potencjał odnawiania znaczeń. W sensie religijnym jest narzędziem dziejącej się historii spirytualnej, której wymiar zakryty jest dla współczesnych (choć nie dla niej, jest ona wywyższona w swej misji). W wymiarze politycznym jest „wzorem walki o prawa polityczne" kobiet, jak czytamy (s. 271). Jej seksualność z kolei wiązana jest z męskimi pragnieniami, które nakładają się na tę postać (w wymiarze szerszym jest ona rozpoznawana w kontekście Freuda, który pisze o niej jako kastrującej kobiecie; szkoda, że te rozważania nie zostały mocniej powiązane z postacią z dramatu Słowackiego, są niejako zawieszone w próżni). Judyta - jak konstatuje Rudaś-Grodzka - nie została włączona do kanonu, zajętego przez inne postaci kobiece, jak Matka Polka, Kobieta Rycerz. Czeka na swoje odkrycie. Czy ono się dokona? Pozostawmy za badaczką pytanie otwartym.

Właśnie - w centrum kanonu patriotycznego oprócz Polonii w imaginarium narodowym znalazło się osobne miejsce dla Emilii Plater. Hasło jej poświęcone odnajdziemy w omawianej publikacji. Napisała je Ewa Toniak, autorka interesującej książki Śmierć bohatera, w której znalazła się obszerna część poświęcona Śmierci putkownika ${ }^{9}$.Tym bardziej dziwi mnie dość pobieżna prezentacja tej - było nie było - kluczowej figury kobiecej, trwale obecnej w kanonie patriotycznym. Mickiewiczowskie mechanizmy konstruowania jak dzisiaj powiedzielibyśmy - figury z „realnej” postaci są znane w literaturze przedmiotu i autorka hasła, „zagęszczając” je na kilku stronach, przedstawia ów ogólniejszy mechanizm. Szkoda, że podobnie jak w niektórych innych ujęciach z leksykonu, zapomina autorka o istnieniu bogatej literatury przedmiotu, a mogłaby skorzystać zarówno z niej (myślę o studium Bachórza ${ }^{10}$, które powinno być bodaj w przypisach przywołane), jak i z własnych badań. Nie powinna też „zapominać” o samym utworze Mickiewicza, właściwie w wywodzie nieobecnym (nie mówiąc o ujęciu kontekstualnym w Grażynie).

Chciałbym jeszcze zwrócić uwagę na inne hasło autorstwa Moniki Rudaś-Grodzkiej. Badaczka odkrywczo pisze o figurze Wandy, sięgając nie tylko do korpusu tekstów, ale i do bogatej literatury przedmiotu, poddawanej konsekwentnej re-lekturze feministycznej i genderowej. Nie ma jednej Wandy - konstatuje autorka hasła - są dwa ujęcia tej figury: rycerka i ofiara.

9 E. Toniak Śmierć bohatera. Motyw śmierci heroicznej w polskiej sztuce i literaturze od powstania kościuszkowskiego do manifestacji 1861, słowo/obraz terytoria, Gdańsk 2015.

10 J. Bachórz O Emilii Plater i „Śmierci pułkownika”. Narodziny i dzieje legendy, w: tegoż Jak pachnie na Litwie Mickiewicza i inne studia o romantyzmie, słowo/obraz terytoria, Gdańsk 2003 (pierwodruk: 1974). 
Rudaś-Grodzka proponuje lekturę świadomą, by tak rzec, nie tylko owej „podwójności" Wandy, lecz także znamienną dla ujęć średniowiecznych kronik i ich przeformułowań w kulturze, w której to perspektywie nakładają się na siebie różne warstwy palimpsestu, jakim stała się figura Wandy. W efekcie koronkowej interpretacyjnej roboty badaczki odczytane zostaną takie warianty owej figury jak: Wanda - królowa Smoków (legendowy pierwiastek podkreśla obrzędy ponownych narodzin), Wanda Bendis (jako wcielenie Bogini Dziewicy), Wanda Parthenos (dziewiczość jako klucz do autonomii kobiety). Wanda jest więc bytem niepochwytnym, raz ukrywającym, innym razem odsłaniającym ruch znaczeń, wpisywanych w tę figurę w różnych czasach.

W tym trochę „niesprawiedliwym” omówieniu - ów cudzysłów podkreśla niemożność pełniejszej prezentacji haseł w niniejszej recenzji - warto zwrócić uwagę na bohaterki pozytywistyczne. Zacznę od "Siłaczki” (autorstwa Agnieszki Mrozik), znakomicie pomyślanego i "gęstego" hasła, zawierającego także bogate odniesienia kontekstualne, odsyłające do innych haseł (które zostały poświęcone bohaterkom Żmichowskiej, Orzeszkowej czy Kraszewskiego). Propozycję Żeromskiego autorka umieszcza właśnie w szeroko zarysowanym kontekście emancypacyjnym, wskazując na niekoniecznie progresywny charakter owego myślenia w II połowie XIX stulecia (podkreślają to też inne autorki haseł, jak Iwona Wiśniewska, pisząca o Madzi Brzeskiej czy Lena Magnone - o bohaterce Marty Orzeszkowej). Stasia Bozowska - stająca się w procesie recepcji „Siłaczką," pozbawioną imienia i nazwiska, symbolem pewnej postawy, altruistycznej, jak uczono mnie w szkole, z gruntu romantycznej - w świetle lektury feministycznej w punkcie wyjścia jest bohaterką postrzeganą z perspektywy patriarchalnej. Ale to się zmienia. Jak dowodzi autorka hasła, można przeczytać inną historię Bozowskiej - Siłaczki, idąc dalej w dookreśleniu nauczycielskiego projektu emancypacyjnego. W takim świetle postawa Siłaczki staje się figurą nie tyle cichej klęski, lecz urasta do rangi wywrotowej. Jeśli w tamtej epoce do kształcenia kobiet w dominującym dyskursie odnoszono się dosyć podejrzliwie, to jednak Żeromski przekracza wymiar ów ironiczno-tragiczny (do tej pory dominujący w tradycyjnych odczytaniach). Agnieszka Mrozik udowadnia, że nauczycielstwo staje się tu co prawda swoistym zakonem (kobiety-nauczycielki "pozbawiane” są ciała, pragnień), ale też można je potraktować jako swoistą formę ucieczki (i oporu) od modelu patriarchalnego, wyznawanego przez czołowych pisarzy (i pisarki) epoki, jako możliwość odmiennego realizowania swego powołania poza rolami „przypisanymi” kobiecie: żony i matki. Takie myślenie oczywiście z czasem zmieniło się, ale w czasach Żeromskiego nadanie „Siłaczce” aury wielkości, 
uwznioślenie jej postawy także niosło potencjał rewizyjny. Dobrze to widać w kontekście bohaterki Prusa - Madzi Brzeskiej, kompetentnie interpretowanej przez Iwonę Wiśniewską. Prus hołdował projektowi „uczłowieczenia” kobiety, nadania jej takich cech, które pozwolą jej osiągnąć pełnię „człowieczeństwa" (określanego poprzez model „patriarchalno-wiktoriański”). To kobieta "czysta", naiwna, o wyostrzonym zmyśle etycznym i, jak ironicznie dowodzi autorka hasła: niezbyt lotna intelektualnie i nieco histeryczna. Prus dzieli uprzedzenia z prawie całą swą epoką (dzielnie mu w tym towarzyszy Orzeszkowa, jak w kilku miejscach przeczytamy: regresywnie korygująca swój wczesny projekt emancypacyjny - zob. hasło „Marta”). A jednak i tu można dostrzec potencjał nowego odczytania: jak wnikliwie dowodzi Wiśniewska, Madzia to bohaterka o „podwójnym” statusie: niby słaba, ale jest spiritus movens najważniejszych zdarzeń. Co więcej - na jej niedojrzałość można spojrzeć inaczej, przez pryzmat niestałego, niegotowego podmiotu o cechach podobnych do podmiotowości nowoczesnej (autorka hasła sięga tu po koncepcję Joanny Zajkowskiej"1). To zapewne dyskusyjne ujęcie, ale bardzo ożywcze, pozwalające inaczej spojrzeć na inne bohaterki Prusa (także na bohaterki kobiece z Lalki). Madzia jest rozpoznawana w kilku odsłonach: jako bohaterka nieuświadamianych tęsknot erotycznych, melodramatyczna heroina, bohaterka szukająca sensu życia w klasztorze, ale też jako przypadek neurotyczny i postać komiczna. Można więc zapewne mówić o jakiejś „niepochwytności” Madzi, co niejako „ożywia” ją jako postać, wydobywa z wiązki stereotypowych odczytań, jakkolwiek nie sposób nie zauważyć, że jest ona silnie związana ze stereotypowymi elementami kobiecości wiktoriańskiej.

Warto w kilku słowach przywołać figurę „Marty” - powieściową realizację projektu emancypacyjnego Orzeszkowej. Da się on zawrzeć w słowach: „kobiety są w społeczeństwie nie upośledzone, lecz zanadto rozpieszczone i wywyższone” (s. 416). Należy je więc w świecie, który przypisał im tradycyjne role, przygotować do stania się w pełni „człowiekiem”, tzn., by zdobyły życiową samodzielność. Ale bohaterka Orzeszkowej, w zwarciu z życiem, ponosi klęskę. Lena Magnone napomyka o Agambenowskim "nagim życiu” jako jedynym, co Marta ma do zaproponowania światu. To nie pozwala na ucieczkę przed ostateczną klęską. Rzeczywiście dość dziwna wydaje się ugodowa strategia emancypacyjna Orzeszkowej - pisarki, u której w twórczości do głosu dochodzą akurat inne cechy niż w jej życiu. Ale jak w zakończeniu wywodu

11 J.Zajkowska Nowocześni bohaterowie Prusa, w: Bolesław Prus: pisarz nowoczesny, red. J.A. Malik, TN KUL, Lublin 2009. 
podkreśla autorka hasła - może była w tym pragmatycznie przemyślana strategia, pozbawiona „rewolucyjnego” wymiaru i tym samym pozwalająca na stopniowe drążenie społecznej skamieliny.

Jeżeli z końca XIX wieku przeniesiemy się do bliższych nam czasów, to możemy zwrócić uwagę na wywrotowy potencjał takich postaci jak „Hela traktorzystka" (hasło autorstwa Agnieszki Mrozik).W tym doskonale udokumentowanym ujęciu zinterpretowana została figura traktorzystki, najpierw $\mathrm{w}$ wersji à la russe sovietique (wcielała ona najpierw komunistyczny tryumf młodości, później sowieccy twórcy nadali traktorzystce cechy dostojniejsze, co wiązało się z odejściem od porewolucyjnej fazy nieskrępowanego wyzwolenia z uprzednich "przesądów” moralności burżuazyjnej). Podobny impet propagandowy miała polska "traktorzystka Hela" (w którą wcieliła się autentyczna Magdalena Figur). Jak dowodzi autorka hasła - w dzisiejszym stereotypowym widzeniu PRL- $u$, zwłaszcza pierwszych jego lat, zatracony został w potocznym odbiorze nie tyle wywrotowy charakter figury traktorzystki, ile jej potencjał emancypacyjny, który wielu kobietom dał - w realnym życiu - możliwość osiągnięcia samodzielności zawodowej i życiowej (wszakże dzisiejsza interpretacja feministyczna podkreśla, że figura traktorzystki jest swoistym - może i niechcianym - symbolem innej modernizacji niż ta zachodnia, odrzuconej, ale zawierającej spory ładunek wywrotowy, także w sferze realnego awansu zawodowego, społecznego, odkrycia kobiecej niezależności). Ale w świecie PRL-u z drugiej strony istniał silny opór przeciwko propagowaniu wzorca kobiet na traktorach. Utożsamiały one odwrócony porządek ról społecznych, a tego było już za wiele, przyjść więc musiało kontruderzenie. Po październiku 1956 to władze zainicjowały ów oczekiwany społecznie powrót do „normalności”. A po przełomie 1989 odesłano "traktorzystkę Helę" - jak możemy wnioskować po lekturze hasła, zbyt pospiesznie - do lamusa historii. A przecież - konkluduje Mrozik - można tę figurę przeczytać, odnosząc ją do nurtującego dzisiejszy świat problemu prekariatu, bezrobocia kobiet, przemian pracy.

Jak już wspominałem - żałując tego wielce - w omówieniu zawartości leksykonu z konieczności muszę skupić się na arbitralnym przecie, wiem o tym dobrze, wyborze. Na koniec chciałbym więc słów kilka powiedzieć o haśle zatytułowanym „Natalia w Brooklynie” - od piosenki Kazika - wiążącym się, w sposób wszakże nieoczywisty na pierwszy rzut oka z hasłem o traktorzystkach i wcześniejszych figurach emancypacji. Ale jest tu - i w innych hasłach, na inne sposoby to się manifestuje - owo mniej czy bardziej jawne wiązanie. Natalia w Brooklynie i jej podobne postaci z kultury polskiej 
ostatnich dziesięcioleci to kobiety-emigrantki, wykuwające swój los z emancypacją w tle, także i dzisiaj: sprzątają, opiekują się starymi ludźmi, stoją „na zmywakach”. To niskopłatne prace, ale dla wielu jedyne możliwe do wykonywania. Zwłaszcza kiedy alternatywą dla „takiej” pracy jest jej brak w tysiącach polskich miast i miasteczek. Wytworzony wcześniej stereotyp dość jednoznacznie charakteryzował owe współczesne „pomywaczki”, ale jak dowodzi autorka hasła - Marta Taperek - współczesna kultura zdołała przeformułować ów stereotyp. W przeciwieństwie do książek pisanych przez mężczyzn-emigrantów te pisane przez kobiety inaczej tworzą figurę współczesnej emigrantki: „To właśnie te ambitne i gotowe na wyzwania nowoczesności kobiety przełamują dziś tradycyjną, postzależnościową i postkolonialną narrację w literaturze polskiej" (s. 491).

Przytoczone zdanie - po dokonaniu modyfikacji stylistycznej - można potraktować jako i motto, i podsumowanie omawianego obszernego tomu. Podkreślić warto, że ambitne przedsięwzięcie naukowe jest zdolne - w swym potencjale wywrotowym - przełamać dotychczasowe odczytania postaci kobiecych, a tym samym nawet jeśli nie zastąpić, to przynajmniej podważyć istniejący w potocznej świadomości kanon figur organizujących zbiorową wyobraźnię. Owo rozruszanie kanonu jest gestem bardzo ważnym, także w perspektywie „odczarowania” słowa w potocznej świadomości bodaj dziś najbardziej „przeklętego" i „wyklętego” jednocześnie. „Gender” po lekturze omawianej publikacji może stać się terminem inaczej rozumianym, niż chcą tego ci, z tym słowem i tym, co się za nim w rzeczywistości kryje, walczący. Wkraczam jednak na inny zgoła teren niż ten, po którym poruszałem się, pisząc omówienie leksykonu. A marzycielem - choćby naiwnie wierzącym w możliwość zmiany - warto pozostać. 


\section{Abstract}

\section{Arkadiusz Bagłajewski}

MARIA CURIE-SKŁODOWSKA UNIVERSITY (LUBLIN)

Woman, Figure, Canon

Review: ...czterdzieści i cztery. Figury literackie. Nowy kanon [...Forty-Four: Literary Archetypes - A New Canon] ed. by M. Rudaś-Grodzka, B. Smoleń, K. Nadana-Sokołowska, A. Mrozik, K, Czeczot, A. Nasiłowska, E. Serafin-Prusator, A. Wróbel (Warsaw: Wydawnictwo IBL PAN, 2017).

\section{Keywords}

gender studies, feminism, archetypes, canon, lexicon. 